\title{
A Critical Analysis of Disability Policy and Practice in Flanders: Towards Differentiated Manifestations of Interdependency
}

\section{Keywords}

Welfare reform, intellectual disabilities, welfare in/dependency, disabled human subject, solidarity

\begin{abstract}
Notions of citizenship and disability rights denote abstract, ambiguous and contested principles, and realising these ideas entails complexity in practice. This is particularly the case since the welfare state is no longer conceived as the principal provider of welfare services and resources in many European welfare states. In that vein, we critically analyse the underlying principles, rationales, values and potential implications of the White Paper 'Perspective 2020: a new support policy for disabled people' in Flanders (the Dutch speaking part of Belgium). We tease out which understanding of the disabled human subject is promoted by this so-called innovative social policy, and excavate how policy makers and a diversity of actors involved in the policy implementation process consider the provision of care and support. Our main argument entails that the welfare state should acknowledge and vindicate differentiated manifestations of interdependency rather than reinforcing a dichotomy that is based on notions of in/dependent human subjects.
\end{abstract}




\section{Authors}

Griet Roets ${ }^{\mathrm{a}^{*}}$, Vanessa Dermaut ${ }^{\mathrm{b}}$, Toon Benoot ${ }^{\mathrm{a}}$, Claudia Claes $^{\mathrm{e}}$, Tineke Schiettecat ${ }^{\mathrm{a}}$ and $\mathrm{e}$, Rudi Roose $^{\mathrm{a}}$, Wim Van Lancker ${ }^{\mathrm{c}} \&$ Stijn Vandevelde ${ }^{\mathrm{d}}$

${ }^{a}$ Department of Social Work and Social Pedagogy, Ghent University, Dunantlaan 2, 9000 Ghent, Belgium.

${ }^{b}$ vzw UNIE-K, W. Elsschotstraat 19/1, 8870 Izegem, Belgium.

${ }^{c}$ Centre for Sociological Research, Parkstraat 45 box 3601, KULeuven, Leuven, Belgium.

${ }^{d}$ Department of Special Needs Education, Ghent University, Begijnhoflaan 464, 9000 Ghent , Belgium

${ }^{\mathrm{e}}$ Equal Research Centre, University College Ghent, Campus Schoonmeersen, Valentin Vaerwyckweg 1, 9000 Gent

*Corresponding Author: Griet.Roets@ugent.be

\section{Table of Contents}

Introduction

Methodology

Findings

Perspective 2020

Competent citizen-consumers buying care and support

A shift to welfare pluralism and subsidiarity: the role for families and communities

Discussion

Conclusion: towards differentiated manifestations of interdependency

References 


\section{Introduction}

In the course of the twentieth century, principles of citizenship and social rights have been conceived and acquired symbolic and institutional value as a key aspect of political thinking across modern welfare states (Dean, 2015; Lister, 2007). Citizenship and social rights conventionally refer to the construction of the relationship between individuals and the state, and between individual citizens within their community (Lister, 2007). Governments have also explicitly adopted the rhetoric of citizenship and rights of disabled people as a driver of social policy debates and practices (Ellis, 2006; Lid, 2015; Van Gennep \& Van Hove, 2000). However citizenship and rights are abstract and ambiguous concepts and principles in social policy making (Dean, 2015; Lorenz, 2016), and might lead to ambiguous implications in practice; being "contested at every level from its very meaning to its political application, with implications for the kind of society to which we aspire" (Lister, 1997: 3; see also Lister, 2007; ) .

Also for the policy rhetoric of citizenship and disability rights to become a reality in disability policy and practice in intellectual disabilities, a persistent and critical commitment is therefore required (Carey, 2003). Although many governments might indeed talk the talk on citizenship and disability rights, in reality societies often do not walk the walk due to the discrepancy between the formal citizenship (embodied as an entitlement and a status) of people with intellectual disabilities and their de facto citizenship (constructed through the experience of being a member of a particular community and society in practice) (Author, 2008; Author, 2019). In that vein, the United Nations' Convention on the Rights of People with Disabilities was adopted by the UN General Assembly in 2006, entered into force in 2008, and was accordingly ratified by a wide variety of modern welfare states. The Convention is a legally binding international human rights treaty that reinvigorates the intention to promote, protect and fulfil the rights and dignity of disabled people (see Convention of the Rights of People with 
Disabilities, 2006; Harpur, 2012). This critical commitment is even more vital since modern welfare states have experienced growing social and economic pressures on the principle that the state is conceived as the main provider of welfare services and resources (Lorenz, 2016). This was "accompanied and fueled by a significant backlash against social rights" (Dean, 2015: 37), and reflected in the current climate of an active restructuring of public spending, austerity measures and the continuous rationing of resources (Dean, 2015; Garrett, 2018), particularly in liberal welfare states where the rights-based entitlement to public services for disabled people is currently under pressure (Ellis, 2006; Garrett, 2015; Mansell, 2006).

Given this context, we focus in this article on the underlying principles, rationales, and normative value orientations in contemporary rhetoric in disability policy and practice in Flanders (the Dutch speaking part of Belgium). In 2010, the Minister of Welfare, Public Health and Family Affairs launched a White Paper 'Perspective 2020: a new support policy for disabled people' that is explicitly concerned with the citizenship and rights of disabled people (see Department of Welfare, Public Health and Family Affairs, 2010, 2013, 2018). In this article, we engage in a critical analysis of policy development rationales and macro-level debates about these rationales during the policy implementation process in Flanders as an entry point. Our contribution captures both a contextual analysis of the policy development rationales of Perspective 2020, which involves an analysis of how "policies that align basic concepts, principles, procedures, or protocols, and policy-specific goals and associated outcomes" are established (Author, 2017: 247), and of how the rights-oriented value base of Perspective 2020 is interpreted during the policy implementation process (see Author, 2017). Although the policy of Perspective 2020 is currently almost at the end of its life cycle in Flanders, it is important to scrutinize the policy development rationales and policy implementation processes since the key foci are likely to remain in the next policy plan of the Flemish Government in 2020-2025. Moreover, we have a specific interest in the implications for people with intellectual disabilities 
since they often are a minority group amongst other citizens. Starting from this perspective, we therefore tease out which understanding of the disabled human subject is promoted by this potentially innovative social policy (see also Mladenov, 2012).

\section{Methodology}

The finding that citizenship and disability rights might entail complexity when these principles are implemented in practice with and for people with intellectual disabilities underlines the importance of a critical analysis of how notions of disabled people's citizenship and disability rights are encompassed as politically significant in the formal rhetoric of social policy makers, but especially during the policy implementation process. We therefore apply a critical discourse analysis to open up the complexity of political discourse as a form of social practice which both constitutes the social world and is constituted by other social practices and institutions from a critical social standpoint (Fairclough, 2003). Discourse is considered as socially constitutive as well as socially shaped: "it constitutes situations, objects of knowledge and the social identities of and relationships between people and groups; it is constitutive both in the sense that it helps to sustain and reproduce the status quo, and in the sense that it helps transforming it" (Hyland \& Paltridge, 2011: 39-40). Critical discourse analysis also enables researchers to understand discourses in their broader social, cultural and political context (Jorgensen \& Phillips, 2002), making opaque power relations and ideologies manifest along the lines of more equal power relationships in society while recognising that power relations are discursive (Jorgensen \& Phillips, 2002; Weiss \& Wodak, 2003). This approach therefore allows us to identify particular ways of representing and framing aspects of disability policy and practice due to the influence of Perspective 2020 in Flanders, and is highly relevant since social policy rhetoric concerning disability services is potentially deceptive and even paradoxical in the case of people with intellectual disabilities (Lister, 2007; Moonen, 2015). In that sense, Van Gennep (1997) aptly 
refers to the risk of 'swindling labels', resulting in the telling of 'pseudo-citizenship lies' in social policy that is supposed to benefit people with intellectual disabilities' lives and wellbeing but rather curtails their citizenship and rights.

We used an applied form of text-based critical discourse analysis in our study (see Fairclough, 2000; Wodak \& Meyer, 2009; Hyland \& Paltridge, 2011), focusing accordingly on the policy development and implementation process of this welfare reform in disability policy and practice in Flanders during the last decade. Our intent is to grapple which underlying notions of the disabled human subject are at stake in the policy rhetoric, and how these underlying assumptions about related discursive practices of care and support might benefit or have an unfavourable effect on the citizenship and rights of people with intellectual disabilities as a particular social minority group. We therefore engaged in a combination of a scoping literature review in the international body of research and literature on these topics (see Arksey \& Malley, 2005; Munn et al., 2018) with a discourse analysis of the underlying principles, rationales and values of 'Perspective 2020: a new support policy for disabled people' that are captured in a diversity of the key policy documents, both in the policy development and policy implementation process.

Whereas the scoping literature review synthesizes the existing body of research knowledge in the international research community, the discourse analysis consists of a close and critical cross-reading of contextual and central policy documents. For the latter, we selected and analysed central policy documents being produced by the Flemish government (see Department of Welfare, Public Health and Family Affairs, 2010, 2013) and policy documents being produced by the Flemish Agency for Disabled People (VAPH) during the implementation process. The entry for the selection of these policy documents was based on the role of main 
Advisory Commission ${ }^{1}$ of the VAPH, which is the Flemish Government Agency that has a transversal position across policy domains. It is however important to note that although policies being developed by the VAPH are meant to contribute to an inclusive policy, the policies itself only cover the field of care and support. Other policy domains, such as employment, education and lifelong learning, tourism, cultural activities and leisure time, mobility, housing, and sports, have to be taken into account as well in inclusive and horizontal ways (see Decree on Equal Opportunities, 2008).

Hence, our analysis is also based on a selection of public policy documents that were produced by the Advisory Commission and related thematic study groups during the policy implementation process of Perspective 2020. We included a diversity of policy documents since the structure and organizational culture of the VAPH reflects principles of active participation. As such, the selected documents capture the rationales, aims and macro-level debates from a diversity of perspectives and the review of what has been realized during the last 10 years (see SARWGG, 2013; Department of Welfare, Public Health and Family Affairs, 2015; VR, 2016, 2017, 2018; VAPH, 2019).

\section{Results}

\section{Perspective 2020}

In the White Paper Perspective 2020, the Minister of Social Welfare, Public Health and Family Affairs in Flanders proposes a profound change of the welfare settlement, explicitly adhering to principles of citizenship, social rights, solidarity and inclusion. In the policy document,

\footnotetext{
${ }^{1}$ The Advisory Commission is perceived as the medium to enable the following representatives to participate: disabled people, a diversity of disability advocacy organizations and publc services, professionals in public disability services including trade unions, and 6 independent experts. The Advisory Commision also organizes thematic study groups which include a broader group of representatives.
} 
reference is made to the United Nations' Convention on the Rights of People with Disabilities, which was ratified and implemented in Belgium in August 2009. The Convention expresses and reinvigorates the intention to protect the rights and dignity of disabled people. According to Harpur (2012: 5), the promising potential of the Convention implies that disability is regarded as "an aspect of social diversity", and therefore social rights can now be applied to realise true equality.

In Perspective 2020, it is argued that this ratification demonstrates the intention of the Belgian and Flemish government to actively realise the rights of disabled people, as "the convention intends to enable disabled people to enjoy the full realisation of their rights while treating them on equal terms through urging the authorized states $(\ldots)$ to create appropriate environments and measures" (Department of Welfare, Public Health and Family Affairs, 2010: 3, our translation). In that sense, the policy document prominently proclaims an underlying and innovative paradigm shift from a care- to a support-oriented approach, that finds its basic underpinnings in the inclusive features of a "model of citizenship in which quality of life is a central component (...), implying an emphasis on the potentials, individual skills, personal autonomy [of disabled people] and social solidarity [in society]" (Department of Welfare, Public Health and Family Affairs, 2010: 4, our translation). This is recently manifested in Flemish policy and practice through two central and interrelated cornerstones of this alleged innovative paradigm shift: whereas the first aspect refers to a shifting underlying assumption of what it means to be a disabled human subject with an emphasis on competent citizenconsumers who buy their own care and support, the second aspect excavates the ideas of how policy makers proclaim a shift to welfare pluralism and subsidiarity.

\section{Competent citizen-consumers buying care and support}


Dominated by a concern to 'liberate' disabled citizens from the state, "the view of citizens as consumers of public services has been a consistent and expanding focus" (Clarke, 2005: 449) in countries such as the Netherlands, the United Kingdom and Australia. This shift is mainly informed by a key mantra of choice: “customers, however vulnerable or confused, must choose their service provider or have the opportunity to do so", being financed, by allowances or vouchers provided to citizens to enable them to purchase services in the market place and compelling them to choose between providers and so driving competition (Dean, 2015: 16). In a diversity of countries, principles and practices of cash benefits or direct payments have been welcomed as an essential condition for the promotion of disabled people's freedom and independence, demanding the relocation of welfare resources from institutionalized and professionalized care to "self-driven consumers who sovereignly wield the power to buy" (Mladenov, 2012: 251; see also Dowse, 2009; Mladenov, Owens, \& Cribb, 2015). In that vein, a market is created with competing providers of disability services, turning service users into customers who have a choice and should demand quality. In the context of newly emerging, fundamental social and economic challenges in the last decades of the twentieth century, many European countries have made greater use of market-based and managerial principles and policies to restructure welfare provision (Hood, 2014; Otto, Polutta, \& Ziegler, 2009).

Disabled people have also been reframed in Flemish social policy rhetoric as competent stakeholders and citizen-consumers who can buy their own care rather than as service users. Perspective 2020 strongly accentuates that disabled people should be able to fully develop their own potential and to rule over their own lives. Therefore it is argued that "initiatives that contribute to the strengthening of personal autonomy and self-determination should accordingly be developed" (Department of Welfare, Public Health and Family Affairs, 2010: 4). The focus on personal autonomy has been translated as a shift from supply-oriented provisions to demanddriven services, resulting in a new system of vouchers and personal cash payment budgets 
which allow disabled people - as consumers - to buy their care and support (Department of Welfare, Public Health and Family Affairs, 2010, 2018).

In Flanders, similarly disability services are required to function in a more 'business like' way "by generating funding mechanisms that require providers to compete with one another" (Dean, 2015: 15). The government is explicitly expecting from disability services that they develop according to a paradigm of social entrepreneurship (Department of Welfare, Public Health and Family Affairs, 2010). For disability services, this shift to a paradigm of social entrepreneurship implies that economic survival strategies are to be developed. While disability services were previously publicly funded and supply-oriented, they are currently expected to attract disabled people in demand-driven ways to purchase and buy their care and support while using their personal cash payment budgets. The system comprises directly accessible care and support services that are supported by a basic budget (step 1), non-directly accessible care and support services supported by a personal budget (step 2), and organisations who are expected to offer flexible and advice, support and clarification in finding the 'right' support (VAPH, 2019).

Although the policy plan in Flanders mentions that even disabled people who experience the most severe need for care and support are guaranteed "adequate, appropriate, and high-quality support at socially acceptable and justified cost" (Department of Welfare, Public Health and Family Affairs, 2010: 22, our translation; VAPH, 2019), the debates in Flanders show that this move to an increasingly personalized choice in a free and flexible market of service delivery creates a number of challenges when disabled people, and specifically people with intellectual disabilities and/or mental health problems, are perceived as consumers who are expected to be competent in guaranteeing that care and support will take place with enough professional expertise (Decree Flemish Government, 2016, 2017, 2018). During the policy implementation 
process, necessary revisions are already captured in the Decree of 2017 which shows that surplus legal protection and quality control is necessary and will be pursued to guarantee this (see also VAPH, 2019). The Decree of 2018 also stresses the major concerns about the shift to self-determination, stating that "many service users today are not capable in managing their own budget, both in terms of costs for care, housing and living conditions. The shift to selfdetermination requires specific competences of service users which causes major concerns, both on the side of disabled people and their families, and providers of care and support" (Decree Flemish Government, 2018: 4). The Decree therefore stresses the need for further revisions during a period of transition until 2021, during which service users will be receiving better support in managing their budget and providers of care will be controlled by the Flemish Government, issuing rules that should guarantee fair and transparent costs. With reference to situations where the disabled citizen is not capable of self-management, free choice and selfreliance, however, Perspective 2020 asserts that new diagnostic instruments are made operational that allow an assessment of which formal and/or informal supports are desirable and can be used. This brings us to the second aspect of how the provision of care and support is perceived.

\section{A shift to welfare pluralism and subsidiarity: the role of families and communities}

In the international realm, what is called 'welfare pluralism' or a 'mixed economy of welfare' (see Williams, 2001; Dean, 2015) rests on the idea that an increasingly significant level of provision should also come from the 'informal sector', meaning from families and communities. Here, "everyday care and support that people provide for one another within households and neighbourhoods" is supposed to be reconciled with the responsibility of the state as a provider of welfare resources and services (Dean, 2015: 14). In Flanders, policy makers introduce the notion of 'vermaatschappelijking van de zorg', a catch-all concept that is 
difficult to translate (see for a similar idea of a 'Big Society' in the UK, see Goodley and Runswick-Cole, 2015) and a 'participation society' that has been formally introduced and implemented in the Netherlands (see Grootegoed, Broër, \& Duyvendak, 2013; Koster, 2014; Van Hees, Horstman, Jansen, \& Ruwaard, 2015). In Flemish disability policy, "the promotion of support of the social network (volunteer aid) in the direct environment of disabled people" is perceived as a central policy imperative (Department of Welfare, Public Health and Family Affairs , 2010: 5, our translation). The policy rationale of 'vermaatschappelijking' embodies the connotation of organising care and support with/in the community and society; "a paradigm shift in pursuit of an inclusive approach towards disabled people (...), allowing them to acquire their own meaningful and particular place in society while embracing both their vulnerabilities and strengths, supporting them in this venture where necessary, and organising care and support with, and integrated in, society as far as possible" (Department of Welfare, Public Health and Family Affairs , 2013: 4).

In that sense, an integral and dynamic model of 'concentric circles' has been based on a notion of the American Association of Intellectual and Developmental Disability (AAIDD), that introduces a novel conceptualisation of support needs and resources (see Buntinx, 2013). In the original framework, a differentiation is made between services and supports in the conceptualisation of resources; the latter are perceived as a broader and more overarching series of material as well as immaterial resources rather than resources that are exclusively being embedded in ideas of self-management and support offered by families and communities (Buntinx, 2013). The AAIDD conceptualisation of support resources is framed as a strengths-based approach that may be relevant even in the case of very severe and multiple disabilities; "the person can be pictured in the middle of a set of concentric circles" (Buntinx, 2013: 14). Actors in the first three circles are considered as natural resources that are available 
in the general community environment, whereas actors in the fourth and last circle concern specialized services-based resources (Buntinx, 2013).

In the Flemish policy plan, it is argued that the promising potential of this approach implies that it displays "the need for care and support of disabled people by means of a dynamic support system that includes five concentric circles. Every circle represents one of the actors involved that can play a pivotal part in the organisation of the care and support for a particular disabled person" (Department of Welfare, Public Health and Family Affairs, 2013: 5). Rather than adopting the broad definition of supports as material as well as immaterial resources from the AAIDD model, support is mainly captured in terms of support offered by persons. In its Flemish translation, the five concentric circles include, firstly, self-management of care; secondly, care offered by nuclear family members; thirdly, care provided by family, friends, and informal contacts with volunteer community members; fourthly, formal care offered by professionals in public services that are accessible for all citizens; and fifthly, formal care provided by professionals in specialised public services.

In the original model, it is argued that the support resources in the first three circles are inclusive to persons with disabilities. It is argued that the shift in thinking reveals a historical turning point, as "the tide turned, and persons with disabilities began to make use of their natural support resources" whereas previously specialized services separated them from the same functions and organisation in the community at large (Buntinx, 2013: 14).

The AAIDD conceptualisation, however, might be problematic in the suggestion that an inclusive society already exists, which is - as research recently uncovers - not the case in Flanders (see Author, 2016). Although there has been an emphasis on de-institutionalization and community-based care, many institutions continue to exist and shifting and changing paradigmatic ideas in disability policy and practice do not clearly result in recognition and 
respect for people with intellectual disabilities in social interactions (see Author, 2003, 2016). It is also striking that the shift to a market-oriented approach in disability policy and practice in Flanders has not resulted in major changes, since the welfare reform results for many people with intellectual disabilities in a subtle shift in funding mechanisms (with reference to the fact that the majority uses vouchers to 'buy' the same care) rather than in other or better and more flexible care and support practices and a better quality of life (see author, 2019).

Moreover, the AAIDD recognises that although the primary reason for making use of natural resources is the common sense that people with disabilities are and want to be part of their community, the concentric circles approach "might be seen by some politicians as a rationale for budget cuts" (Buntinx, 2013: 14). In that vein, the application of the concentric circles approach in Flanders is meant to underpin an objective identification and classification of the impairments and needs of disabled people, and a framing of judgements about eligibility for disability services that allow a sound assessment of when situations are experienced as a kind of 'predicament'. In cases of predicament, the extent to which "the severity and gravity of impairments in (practically) all situations exceeds the capacity of the environment (volunteer aid, social network, regular care provisions)" (Department of Welfare, Public Health and Family Affairs, 2010: 23, our translation) stipulates whether disabled people can make use of public disability services. Although there is supposedly no hierarchy but complementarity between informal and formal care, this development of 'vermaatschappelijking' also squares with the idea that the public responsibility for the welfare of citizens should be rebalanced with, and even returned to, the private responsibility of the individual, his/her natural social networks (such as family members) and the community/civil society (Dean, 2015). The policy plan significantly mentions that the underlying and so-called innovative paradigm shift from a careto a support-oriented approach, which is supposed to reflect a model of citizenship, goes hand in hand with "the investment in the creation of natural and informal networks around disabled 
people as an additional source of support [which] will help us to modify the system, in the sense that it enables us to support more people with the same amount of financial resources" (Department of Welfare, Public Health and Family Affairs, 2013: 10).

It is argued that the use of person-centred direct payments, that allow disabled people to make use of non-directly accessible care that is publicly funded, will therefore "rest on the remaining support need, after the settlement of the other available sources of support in the natural and social network, and in directly accessible care" (Department of Welfare, Public Health and Family Affairs, 2013: 10). In that vein, the way in which the concentric circles approach has been implemented in Flanders seems to resonate strongly with the principle of subsidiarity that was historically at the heart of the Belgian welfare state, implying that "intervention should not take place at a level higher than necessary; when an individual is in need of care, help should be sought first from the family or local community, or from voluntary associations - the state steps in only as last resort" (Morel, 2007: 620). The implementation effects of 'vermaatschappelijking', or a 'Big Society'/"participation society' have, however, been sharply criticized, since "citizens have to cooperate, participate, and assume responsibility for their own well-being" (Koster, 2014: 49). Besides the growing concerns that care and support offered with/in society do not adequately address the stresses and sacrifices associated with informal care giving (Williams, 2001; Watson, McKie, Hughes, Hopkins, \& Gregory, 2004; Goodley \& Runswick-Cole, 2015), the state has also been criticised for "abandoning its citizens, letting the weakest shoulder carry the heaviest burdens, and destroying the carefully built mechanisms of a rather successful welfare state" (Koster, 2014: 49). It is telling that during the implementation of Perspective 2020, these concerns and critiques have also been raised in Flanders (see Author, 2018) and new professional organisations (called Services for Support Planning, in Dutch DPO) have been increasingly established that are meant to support the selfdetermination capacities of disabled people and their families and informal network (see Decree 
Flemish Government, 2017; VAPH, 2019). No reference is made whatsoever to social class differentials and inequalities. Disabilities usually sit at the intersection of other inequalities, and research has shown that disabled persons and their families run a higher risk to be poor, have less labour market opportunities, and have smaller informal networks (Vinck, Lebeer \& Van Lancker, 2018). In short, they are less able to draw on their natural resources and social capital to safeguard their wellbeing. As such, a focus on personal autonomy combined with a changing role of public services might reinforce existing inequalities.

\section{Discussion}

Ideas of citizenship and rights are not being abandoned in Belgium; the welfare state still aims to protect, promote and secure the fulfilment of citizenship and rights of disabled people by a variety of means. Also in terms of social spending, in Belgium there are no obvious signs of welfare state retrenchment yet (Cantillon, 2017). The intent of our critical analysis here, however, is to open up the complexity of the political discourse in contemporary disability policy in Flanders and the implications for people with intellectual disabilities from a critical point of view (Fairclough, 2003). Based on our critical analysis of contemporary foci in disability policy and practice in Flanders, our main argument however entails that, if citizenship and disability rights are to be realised with and for people with intellectual disabilities, the welfare state should acknowledge and vindicate differentiated manifestations of interdependency rather than reinforcing a dichotomy that is based on notions of in/dependent and in/competent human subjects.

In Flanders current disability policy requires public services to promote disabled citizens' individual freedom and self-determination, reflecting "a challenge to the assumed, allencompassing dependency of the 'cared-for' in care relations and practices" (Williams, 2001: 470). This emphasis is meant to break the dominant dichotomy between care and support/social 
inclusion in the field of policy and practice for people with intellectual disabilities (see Dewaele, van Loon, Van Hove \& Schalock, 2005; McConkey \& Collins, 2010) by restoring the ideal of their independence and self-determination (see Watson et al., 2004; Williams, 2001), yet might surprisingly reinforce the dichotomy between welfare in/dependency and care and support/social inclusion. Indeed, the underlying assumption in contemporary welfare state arrangements entails that disabled subjects are no longer passive and dependent, yet should be active and independent (Fine \& Glendinning, 2005; Clarke, 2005). The current dominance of the political ideology of individual choice in Flemish policy rhetoric frames people with intellectual disabilities as possessing self-interested independency in relation to the market, and mirrors a new preoccupation with treating them and their informal network as competent citizen-consumers who can buy their own care and be in control over how to lead or shape their lives.

There are, however, different points of view in this debate about the relationship between notions of autonomy, in/dependency and the provision of care and support in the lives of people who need care, including people with intellectual disabilities. On the one hand, Mladenov (2012: 252) suggests and defends that this understanding of 'autonomy' that is equated with 'independence' doesn't exclude people with intellectual disabilities who are often deemed incapable to choose and control on their own. He argues that it is not possible for the heterogenous group of people with intellectual disabilities to be 'customers' in the strict sense, because of their lack of capacity for sovereign decision-making, he argues that they can get "support from third persons with the functions of customers (...) others might be involved in one's decision-making without compromising (...) the notions of choice and control" (Mladenov, 2012: 252). He thus frames an equation of 'autonomy' with 'independence' as nonproblematic, as long as this is framed as a particular type of interdependence; "free choice and 
subject-centred control are nevertheless mediated by choice-facilitating practices in which humans engage in their being-in-the-world" (Mladenov, 2012: 252).

Other scholars have argued that this ideal of rational autonomy being equated with independency as a dominant policy discourse is deeply problematic (see Dean, 2015; Dowse, 2009; Lister, 1997; Reindal, 1999; Watson et al., 2004; Williams, 2001; Goodley, Lawthom, Liddiard \& Runswick-Cole, 2019). They argue that these assumptions might have profound implications for people with intellectual disabilities, who have differentatiated and heterogeneous needs (Mansell, 2006). As citizens, however, people with intellectual disabilities might be victims of this political ideology that assumes that they should be in control of their own life and have the ability to choose and do things with or even without support (Reindal, 1999; Author, 2019). As Goodley et al. (2019: 987) assert, “ability is demanded by our postwelfare societies as states draw back, the market moves in and individual consumers take on the self-contained responsibilities expected of the new global citizens". These ideas also fail to address the complexity of the inherently unequal and asymmetrical power relationships in both formal and informal care configurations between disabled people and those providing them with support. Care and support as a practice refers to a value-laden, contested and complex issue and invokes "multiple relations of power" (Williams, 2001: 468). Current policy rationales therefore paradoxically and easily mark people with intellectual disabilities out as different in kind (Williams, 2001), and as incompetent (Dowse, 2009).

This assumption of rational autonomy and independency does not do justice to what it means to be a human subject, for people with intellectual disabilities in particular but also for human beings in general (see Fyson \& Kitson, 2007; Mansell, 2006; Watson et al., 2004). This requires a radical reconsideration of interdependence as the basis to all human interaction, and as a universal feature of the human subject. 


\section{Conclusion: towards differentiated manifestations of interdependency}

In that sense, all human subjects require or give care in the course of their lives; "the giving and receiving of care is imperative to human existence but is experienced differently at various points in the life course" (Watson et al., 2004: 333). Here we argue that the provision of care and support in relation to the realisation of people with intellectual disabilities' citizenship and rights requires a nuanced re-interpretation; one that embraces the notion of welfare interdependency (Lister, 1997). Critical scholars have indeed argued that the suggested sense of autonomy in current policy rhetoric "is conflated with self-sufficiency; sustaining oneself through dependency (...) within one's family is regarded, perversely, as independence" (Dean, 2015: 37). This problem construction of citizenship and rights refers to a distorted perception that obscures a true understanding of the interdependent nature of human relationships.

In that vein, there is only a beginning recognition by the Flemish government that we all are in need of different types of care and support at different stages in our lives, nor of the ways in which needs are contested and renegotiated between individuals within the context of ongoing care and support relationships and the course of ongoing lives (Watson et al., 2004). From a life course perspective, the need for care and support is intrinsically a universal feature of the human condition that tends to be more or less intense but remains as a continuum (Lister, 1997), and requires that we embrace a notion of relational autonomy for all citizens (Williams, 2001; Lid, 2015). As Lister (1997: 114) argues aptly, relational autonomy refers to an autonomous self that "is only made possible by the human relationships that nourish it and the social infrastructure that supports it". We therefore argue that a notion of relational autonomy allows differentiated manifestations of interdependency for all human beings as an essential feature of the human life course and the human condition (Dean, 2004, 2015; Lister, 1997; Williams, 2001), and is of vital importance for people with intellectual disabilities if we want to cherish notions of interdependence, distributed competence, dis/ability, assemblages of 
possibility and human potentialities (Goodley \& Roets, 2008; Goodley, Lawthom, Liddiard \& Runswick-Cole, 2019).

In that vein, Dean (2015) refers to the idea that welfare states realise rights when governments enable their citizens to care not just for their family and neighbours, but also for distant - and let us add, disabled - strangers, mediated by welfare state arrangements and institutions. The principles of universal recognition of all citizens as inherently interdependent human beings makes possible a configuration of the welfare state in which principles of citizenship and rights are constitutive (Dean, 2015). The universal processes of caring for and being cared for "make one aware of diversity, of interdependence, of the need for acceptance of difference, which form an important basis to citizenship" (Williams, 2001: 478).

Our main conclusion thus implies that due recognition should be given to differentiated manifestations of interdependence as an indispensable feature of the human condition, and as quintessential to even complex human relationships that form the basis of disability policy and practice in matters of care and support in situations of people with intellectual disabilities (Fyson \& Kitson, 2007; Lid, 2015). In that vein, as a team we are involved in further research on the policy implementation and evaluation process of Perspective 2020 (see Author, 2017). In one field for further investigation, the strategies of disability service providers in dealing with shifting power relations due to this welfare reform are addressed, more specifically with a on organisational structure, culture and the shift in the status of professional knowledge in relation to the everyday life experience of people with intellectual disabilities and their informal network (Author, forthcoming). Another topic for further investigation concerns the changing relationship between formal and informal caregivers, and the question whether a constitutive rights-based notion of mutual and collective solidarity can be premised on solidarity in the public sphere rather than on a sort of moral duty that is exclusively embedded in the private sphere of informal care (see Author, 2019). 


\section{References}

Author (2008).

Author (2017).

Author (2019).

Author (forthcoming).

Arksey, H., \& O'Malley, L. (2005). Scoping Studies: towards a methodological framework. International Journal of Social Research Methodology, 8(1),19-32.

Buntinx, W. (2013). Understanding disability: a strengths-based approach. In M. Wehmeyer (ed.), The Oxford Handbook of Positive Psychology and Disability (p.7-48). New York: Oxford University Press.

Cantillon, B. (2017). De staat van de welvaartstaat. Leuven: Acco.

Carey, A. (2003). Beyond the medical model: a reconsideration of 'feeblemindedness', citizenship and eugenic restrictions, Disability \& Society, 18(4), 411-430.

Clarke, J. (2005). New Labour's citizens: Activated, empowered, responsibilized, abandoned? Critical Social Policy, 25(4), 447-463.

Dean, H. (2004). The ethics of welfare: human rights, dependency and responsibility. Bristol: The Policy Press.

Dean, H. (2015). Social rights and human welfare. London: Routledge.

Department of Welfare, Public Health and Family Affairs. (2010). Perspectief 2020: nieuw ondersteuningsbeleid voor personen met een handicap [Perspective 2020: a new support policy for disabled people]. Brussels. 
Department of Welfare, Public Health and Family Affairs. (2013). Conceptnota persoonsvolgende financiering voor personen met een handicap [Concept note for direct payments for people with disabilities]. Brussel.

Department of Welfare, Public Health and Family Affairs (2018). Policy white paper. Brussel.

Dewaele, I., van Loon, J., Van Hove, G., \& Schalock, R.L. (2005). Quality of Life versus Quality of Care: implications for people and programs. Journal of Policy and Practice in Intellectual Disabilities, 2(3/4), 229-239.

Dowse, L. (2009). "Some People Are Never Going to be Able to do That". Challenges for people with intellectual disability in the 21st century. Disability \& Society, 24(5), 571584.

Ellis, K. (2006). Disability rights in practice: the relationship between human rights and social rights in contemporary social care. Disability \& Society, 20(7), 691-204.

Fairclough, N. (2000). Discourse, Social Theory, and Social Research: The Discourse of Welfare Reform. Journal of Sociolinguistics, 4(2), 163-195.

Fairclough, N. (2003) . Analysing Discourse: Textual Analysis for Social Research. London: Routledge.

Fine, M., \& Glendinning, C. (2005). Dependence, independence or inter-dependence? Revisiting the concepts of 'care' and 'dependency'. Ageing \& Society, 25(4), 601-621.

Fyson, R., \& Kitson, D. (2007). Independence or protection- does it have to be a choice? Reflections on the abuse of people with learning disabilities in Cornwall. Critical Social Policy, 27(3), 426-436.

Garrett, P.M. (2015). Words matter: deconstructing "welfare dependency" in the UK. Critical and Radical Social Work, 3(3), 389-406. 
Garrett, P.M. (2018). Welfare Words: Critical social work and social policy. London: Sage.

Goodley, D., \& Runswick-Cole, K. (2015). Big Society? Disabled people with the label of learning disabilities and the queer(y)ing of civil society. Scandinavian Journal of Disability Research, 17(1), 1-13.

Grootegoed, E., Broër, C., \& Duyvendak, J.W. (2013). Too Ashamed to Complain: Cuts to Publicly Financed Care and Clients' Waiving of their Right to Appeal. Social Policy and Society, 12, 475-486.

Harpur, P. (2012). Embracing the new disability rights paradigm: the importance of the Convention on the Rights of Persons with Disabilities. Disability \& Society, 27(1), 114.

Hood, R. (2014). Complexity and integrated working in children's services. British Journal of Social Work, 44(1), 27-43.

Hyland, K., \& Paltridge, B. (2011). Continuum companion to discourse analysis. London: Continuum.

Jorgensen, M., \& Phillips, L.J. (2002). Discourse analysis as theory and method. London: Sage Publications.

Koster, M. (2014). Bridging the gap in the Dutch participation society: new spaces of government, brokers, and informal politics. Etnofoor, 26(2), 49-64.

Lid, I.M. (2015). Vulnerability and disability: a citizenship perspective. Disability \& Society, 30(10), 1554-1567.

Lister, R. (1997). Citizenship: Feminist perspectives. London: Macmillan.

Lister, R. (2007). Inclusive Citizenship: realizing the potential. Citizenship Studies, 11(1), 4961. 
Lorenz, W. (2007). Practising history: Memory and contemporary professional practice. International Social Work, 50, 597-612.

Lorenz, W. (2016). Rediscovering the social question. European Journal of Social Work, 19(1), 4-17.

Mansell, J. (2006). Deinstitutionalisation and community living: progress, problems and priorities. Journal of Intellectual and Developmental Disability, 31(2), 65-76.

Mladenov, T. (2012). Personal assistance for disabled people and the understanding of human being. Critical Social Policy, 32(2), 242-261.

Mladenov, T., Owens, J., \& Cribb, A. (2015). Personalisation in disability services and healthcare: a critical comparative analysis. Critical Social Policy, 35(3), 307-326.

Moonen, X. (2015). Is inclusie van mensen met een verstandelijke beperking vanzelfsprekend? Over een inclusieve samenleving in verbondenheid met mensen met een verstandelijke beperking en sociaal kwetsbare mensen met beperkte cognitieve vaardigheden. Inaugurale rede, woensdag 22 april 2015.

Morel, N. (2007). From subsidiarity to 'Free Choice': Child- and elder-care policy reforms in France, Belgium, Germany and the Netherlands. Social Policy and administration, 41(6), 618-637.

Munn Z, Peters M, \& Stern C. (2018)/ Systematic review or scoping review? Guidance for authors when choosing between a systematic or scoping review approach. BMC Medical Research Methodology, 18(143).

McConkey, R., Collins, S. (2010). The role of support staff in promoting the social inclusion of persons with an intellectual disability. Journal of Intellectual Disability Research, 54(8), 691-700. 
Otto, H.U., Polutta, A., \& Ziegler, H. (eds). (2009). Evidence-based practice-modernising the knowledge base of social work? Opladen: Budrich.

Reindal, S.M. (1999). Independence, Dependence, Interdependence: some reflections on the subject and personal autonomy. Disability \& Society, 14(3), 353-367.

United Nations. (2006). Convention on the rights of persons with disabilities. New York: United Nations.

Van Gennep, A. (1997). Paradigma-verschuiving in de visie op zorg voor mensen met een verstandelijke handicap. Tijdschrift voor Orthopedagogiek, 36(5), 189-201.

Van Gennep, A. \& Van Hove, G. (2000). Are citizenship paradigms and inclusion not usable for people with a severe intellectual disability? Comments on a worrying development. Nederlands Tijdschrift voor de Zorg aan verstandelijk gehandicapten, 26(4), 246-255.

Van Hees, S., Horstman, K., Jansen, M., \& Ruwaard, D. (2015). Betekenissen van burgerschap van ouderen in de participatiesamenleving. Een analyse van 'Voor Elkaar in Parkstad'. Tijdschrift voor Gezondheidswetenschappen. 93(5), 191-196.

Vinck, J., Lebeer, J. \& Van Lancker, W. (2018). Non-take up of the supplemental child benefit for children with a disability in Belgium: A mixed-method approach. Social Policy \& Administration, DOI: $10.1111 /$ spol.12457

Watson, N., McKie, L., Hughes, B., Hopkins, D., \& Gregory, S. (2004). (Inter)dependence, Needs and Care: the potential for disability and feminist theorists to develop an emancipatory model. Sociology, 38(2), 331-350.

Weiss; G., \& Wodak; R. (2003). CDA. Theory and interdisciplinarity. London: Palgrave/MacMillan.

Williams, F. (1999). Good-enough principles for welfare. Journal of Social Policy,

Williams, F. (2001). In and beyond New Labour: towards a new political ethics of care. Critical Social Policy, 21(4), 467-93. 
Wodak, R., \& Meyer, M. (2009). Methods of CDA. London: Sage. 